Article

\title{
Phenolics Profile and Protective Effect on Injuried HUVEC Cells of Epicarp Extracts from Kadsura coccinea
}

\author{
Jun Lu ${ }^{1,2, *}$, Ying Zheng ${ }^{1,2}$, Zhenyu Yang ${ }^{1,2}$, Jing Cheng ${ }^{3}$ and Feijun Luo ${ }^{1,2}$ \\ 1 Hunan Key Laboratory of Forestry Edible Sources Safety and Processing, Central South University of Forestry \\ and Technology, Changsha 410004, China; 20171200327@csuft.edu.cn (Y.Z.); 20201100407@csuft.edu.cn (Z.Y.); \\ luofeijun888@csuft.edu.cn (F.L.) \\ 2 National Engineering Research Center of Rice and By-Product Deep Processing, Central South University of \\ Forestry and Technology, Changsha 410004, China \\ 3 Hunan Key Laboratory of Food Safety Science and Technology, Technology Center of Changsha Customs, \\ Changsha 410004, China; chengjing@csc.intra.custom.gov.cn \\ * Correspondence: lujun925@csuft.edu.cn; Tel./Fax: +86-731-85623240
}

check for updates

Citation: Lu, J.; Zheng, Y.; Yang, Z.; Cheng, J.; Luo, F. Phenolics Profile and Protective Effect on Injuried HUVEC Cells of Epicarp Extracts from Kadsura coccinea. Foods 2022, 11, 556. https://doi.org/10.3390/ foods11040556

Academic Editors: Brigitte Deguin, Rosa Tundis and Anne Claire Mitaine-Offer

Received: 22 January 2022

Accepted: 12 February 2022

Published: 16 February 2022

Publisher's Note: MDPI stays neutral with regard to jurisdictional claims in published maps and institutional affiliations.

Copyright: (C) 2022 by the authors. Licensee MDPI, Basel, Switzerland. This article is an open access article distributed under the terms and conditions of the Creative Commons Attribution (CC BY) license (https:// creativecommons.org/licenses/by/ $4.0 /)$.

\begin{abstract}
This study evaluated the phenolics profile and the antioxidative properties of $K$. coccinea fruits epicarp. A total of 13 phenolic compounds (six phenolic acids, four anthocyanins, two flavonols, and one flavone) were identified by ultra performance liquid chromatography coupled with quadrupole time-of-flight tandem mass spetrometry(UPLC-QTOF-MS/MS). Two anthocyanins, cyanidin-3-xylosylrutinoside and cyanidin-3-rutinoside, comprise 30.89 74.76\% and 13.90 46.17\% of the total amount of anthocyanins in K. Coccinea. Cytoprotective effect results evidenced that pretreatment of Human umbilical vein endothelial cells(HUVECs) with Kadsura. coccinea fruits' epicarp phenolic extracts at the concentrations of 50-200 $\mu \mathrm{g} / \mathrm{mL}$ improved the cell viability after exposure to $\mathrm{H}_{2} \mathrm{O}_{2}$ significantly, and inhibited malonaldehyde(MDA) and reactive oxygen species(ROS) overproduction, as well as enhancing the content of superoxide dismutase (SOD) and glutathione Reductase (GR. This study proved that $K$. coccinea is a natural resource of phenolics rich with potential antioxidant ability, which may be valuable for developing nutraceuticals and dietary supplements.
\end{abstract}

Keywords: Kadsura coccinea; antioxidant activity; antioxidative; HUVEC

\section{Introduction}

Oxidative stress occurs due to the imbalance between reactive oxygen species (ROS) and antioxidants, resulting in the excessive production of various pro-inflammatory cytokines and promotion of inflammatory responses, subsequently to damage vital biological molecules cellular biofilm, DNA, protein and other substances, eventually leads to the occurrence of a variety of diseases, such as diabetes, cardiovascular disease, respiratory disease, rheumatoid arthritis and various cancers [1,2]. In recent years, natural products derived from fruits have gained a lot of attention as potential active ingredients against oxidative stress or chemoprevention agents, especially phenolic compounds, many studies suggest that the antioxidant capacity of natural plants is closely related to their total phenolic content and composition [3-5]. Numerous studies from nature resource have shown that phenolic compounds can reduce the level of oxidative stress and increase the antioxidant capacity in the body to prevent and reduce the occurrence of diseases related to oxidative stress [6-8]. So far, more than 8000 natural phenolic compounds have been identified. Therefore, many efforts have been dedicated to finding the role that natural oxidants play in alleviating oxidation, thereby preventing or delaying oxidative stress, and to find new sources of such compounds.

Kadsura Coccinea (Lem.) A.C. Smith commonly known as "heilaohu", is an important medical plant belong to family Schisandraceae, with a long history in the western and southwestern China as a Chinese folk herbal medicine. It is also known as the "Magical 
Medicine of the Dong Nationality" because the Dong nationality ethnic group use the roots and stems to treat several illnesses such as gastric ulcer, rheumatism, sore throats and to relieve pain, and in dispelling flatulence [9] because the abundance of lignans and triterpenoids [10]. Nowadays, much of the research in K. coccinea has focused on the study of the chemical composition and the bioactive compounds of its root, thus resulting in diverse diterpenoids, triterpenoids and lignans gbeing identified. The $K$. coccinea fruit is a succulent edible fruit with a special shape and unique taste. To date, less research has been completed on its phenolic composition and corresponding antioxidant activity, especial for the epicarp, the larger edible parts in the fruit. Therefore, the aim of the present study is to determine their phenolics composition and evaluate the protective effect activity against cell oxidative damage. This experiment firstly evaluated some new phenolic compounds from $K$. coccinea and their protective effect on HUVEC oxidative stress induced by $\mathrm{H}_{2} \mathrm{O}_{2}$. The results showed that $K$. coccinea phenolic extracts administered pretreatment enhanced the antioxidant capacity and alleviated the cell injury caused by oxygen free radicals.

\section{Materials and Methods}

\subsection{Materials and Chemicals}

Two kinds of $K$. coccinea fruit (Zihe and Dahong in Figure 1) were collected from Tongdao County, Hunan Province, $\left(26^{\circ} 54^{\prime} \mathrm{N}, 109^{\circ} 42^{\prime} \mathrm{E}\right)$, China. The scientific identification was performed by Zhonghai Li (College of Food Science and Engineer, Central South University of Forestry and Technology, Changsha, China). HUVECs were purchased from the Institute of Cell Resource Center, Chinese Academy of Science (Shanghai, China), the cell line originated from ATCC (American Type Culture Collection, Manassas, VA, USA). Cyanidin-3-glucoside, protocatechuic acid, $p$-hydroxybenzoic acid, cinnamic acid, syringic acid andvitexin, were purchased from Sichuan Victory Biological Technology Co., Ltd. (Chengdu, China). Ferulic acid, p-coumaric acid, vanillic acid, hyperoside and rutin were purchased from Shanghai Yuanye Bio-Technology Co., Ltd. (Shanghai, China). Fetal bovine serum was purchased from Bioind (Kibbutz Beit Haemek, 25115, Israel). Dulbecco's modified Eagle's medium (DMEM), penicillin, streptomycin and trypsin were purchased from Gibco BRL (Grand Island, NY, USA). Cytotoxicity and the proliferation assay kit was purchased from PROMEGA (Madison, WI, USA). All other chemicals were analytical grade and purchased from the China National Pharmaceutical Corporation (Shanghai, China).

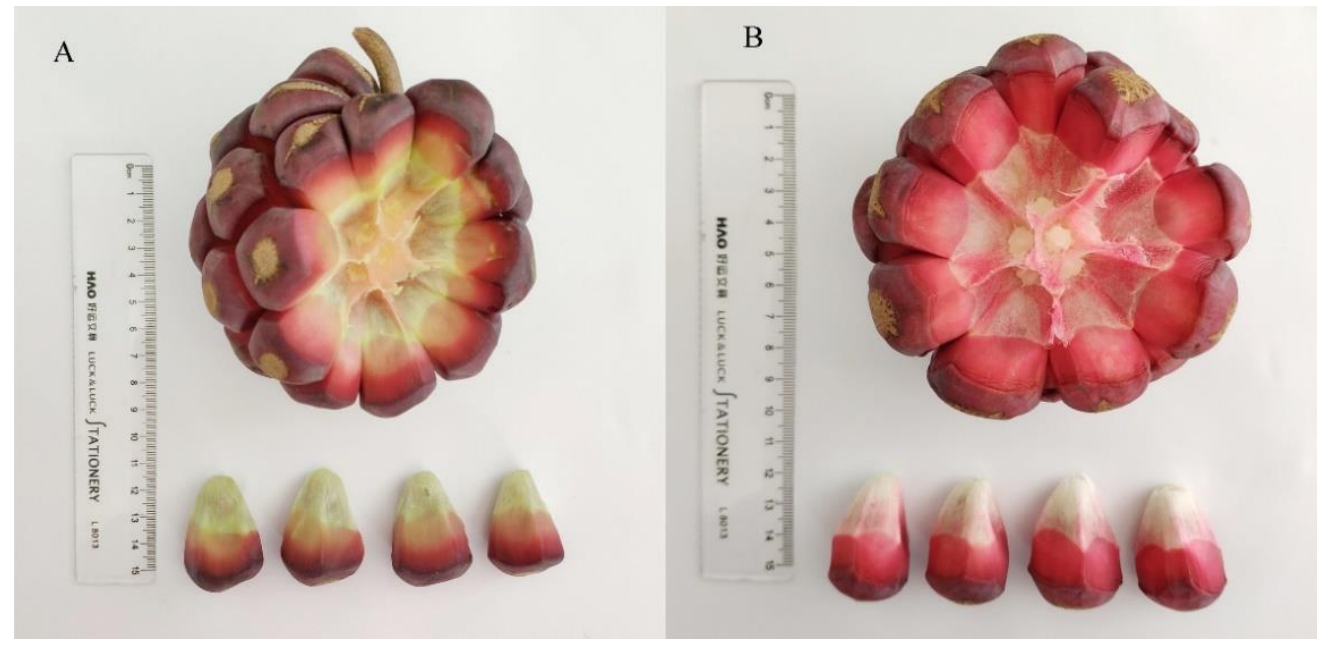

Figure 1. Two kinds of K. Coccinea, Zihe (A) and Dahong (B).

\subsection{Extraction and Isolation of Phenolic Compounds}

The epicarp was manually stripped from the $K$. coccinea fruit and ground with a grinder. A certain quality of epicarp pulping was added with $70 \%$ of ethanol solution (containing $1 \%$ hydrochloric acid) according to the ratio of 1:20 g/mL. After ultrasonic extraction for 
$60 \mathrm{~min}$ in an ultrasonic cleaning machine (Jining, China) at $50{ }^{\circ} \mathrm{C}$, the extracted solution was centrifuged at $4000 \mathrm{r} / \mathrm{min}$ for $8 \mathrm{~min}$. The supernatants were condensed and removed to solvent under reduced pressure. After that, the concentrated solutions were purified with LS-46D macroporous and desorbed with methanol containing $0.1 \% \mathrm{HCl}$. Finally, the desorption solutions were concentrated to remove solvent under reduced pressure at $55^{\circ} \mathrm{C}$. The residue was defined as ZHP for Zihe phenolics extracts and DHP for Dahong phenolic extracts.

\subsection{Determination of Total Phenolics, Total Flavonoids and Total Anthocyanin}

The total phenolics content (TPC) were estimated by Folin-Ciocalteu assay based on the method of Bursal et al. [11]. Gallic acid was used as the reference standard and total phenolic content was expressed as milligrams gallic acid equivalents per gram of fresh weight sample (mg GAE/g). Total flavonoids content (TFC) was determined according to the aluminum chloride colorimetry method [12]. Catechin was used as the reference standard and the total flavonoids content was expressed as milligrams catechin equivalents per gram of fresh weight sample $(\mathrm{mg} \mathrm{CE} / \mathrm{g})$. The anthocyanin content (TAC) in the extracts was measured using the $\mathrm{pH}$ differential method described by Lee et al. [13]. TAC was expressed as mg cyanindin-3-glucoside equivalents per gram of fresh weight sample (mg Gy-3-G/g). The anthocyanin content was calculated according to the following equation:

$$
\text { Total anthocyanins }(\mathrm{mg} \text { Gy-3-G/mL) }=\mathrm{A} \times \mathrm{MW} \times \mathrm{DF} \times 1000 /(\varepsilon \times 1)
$$

where $\mathrm{A}$ is absorbance difference $=\left(\mathrm{A}_{510}-\mathrm{A}_{700}\right)_{\mathrm{pH} 1.0}-\left(\mathrm{A}_{510}-\mathrm{A}_{700}\right)_{\mathrm{pH} 4.5} ; \mathrm{MW}$ is molecular weight of cyanindin-3-glucoside $=449.20 \mathrm{~g} / \mathrm{mol}$; DF is the dilution factor; $\varepsilon$ is the molar absorptivity of cyanindin-3-glucoside $=26,900 \mathrm{~L} /(\mathrm{mol} \mathrm{cm}) ; \mathrm{L}$, pathlength in $\mathrm{cm} ; 1000$ is factor for conversion from $\mathrm{g}$ to $\mathrm{mg}$.

\subsection{Determination of Antioxidant Activity}

In this study, 1,1-diphenyl-2-picrylhydrazyl (DPPH), ABTS (2,2'-azino-bis (3-ethylbenz othiazoline-6-sulphonic acid) diammonium salt) and the Ferric reducing antioxidant power (FRAP) assay were used to evaluate the antioxidant activity of phenolic extracts. The DPPH radical scavenging activity was assayed according to described by Gorjanović et al. [14], with appropriate modifications. The ABTS assay was tested according to the method described by $\mathrm{Oh}$ et al. [15]. The FRAP assay was performed according to the method described by Lu et al. [16]. These antioxidant activities were all expressed as micromole trolox equivalents per gram of fresh weight sample ( $\mu \mathrm{mol} \mathrm{TE} / \mathrm{g})$.

\subsection{UPLC-QTOF-MS/MS Analysis}

A 1290 Infinity UPLC system (Agilent Technologies, Palo Alto, CA, USA) coupled to an Agilent G6495 Triple Quadrupole mass spectrometer (Agilent Technologies, Palo Alto, CA, USA) was used to identify the phenolic compounds. These compounds were separated on an Agilent Poreshell C18 $(150 \mathrm{~mm} \times 2.1 \mathrm{~mm}, 2.7 \mu \mathrm{m}$, Agilent, Waters, Milford, MA, USA) column operated at $35{ }^{\circ} \mathrm{C}$. The eluent system employed was a combination of A (acetonitrile) and B (0.1\% formic acid in water) at a flow rate of $0.3 \mathrm{~mL} / \mathrm{min}$. The gradient varied linearly from $5 \%$ to $95 \% \mathrm{~B}(v / v)$ over $15 \mathrm{~min}$. The mobile phase gradient profile was as follows: $0-1.5 \mathrm{~min}, 97 \% \mathrm{~B} ; 1.5-2.5,80 \% \mathrm{~B} ; 2.5-28 \mathrm{~min}, 40 \% \mathrm{~B} ; 28-31 \mathrm{~min}, 40 \% \mathrm{~B}$. The sample injection volume was $10 \mu \mathrm{L}$. Mass spectra were obtained in the positive and negative modes in a mass range between 100 and1500 Da with the following operating parameters: Air curtain air CUR: 30 PSI; Atomizing gas GAS1: 55PSI; Auxiliary gas GAS2: 60 PSI; Source temperature: $550{ }^{\circ} \mathrm{C}$; Cumulative time: $0.2 \mathrm{~s}$; De-cluster voltage: $70 \mathrm{~V}$. Mass spectra acquisition and data analysis were processed with Masshunter Workstation $\mathrm{B}$ 04.00 software (Agilent Technologies). The identification was achieved by comparison of available standards and references. 


\subsection{Cell Culture and Cell Viability Assay}

HUVEC s were incubated in RPMI Medium 1640 containing 10\% FBS and 1\% double antibody (100 mg L ${ }^{-1}$ penicillin and $100 \mathrm{mg} \mathrm{L}^{-1}$ streptomycin) at $37^{\circ} \mathrm{C}$ in a humidified atmosphere of $5 \% \mathrm{CO}_{2}$. Cells in logarithmic growth phase were placed in 96-well plate at $4 \times 10^{3}$ cells $/ \mathrm{mL}, 100 \mu \mathrm{L}$. The $\mathrm{H}_{2} \mathrm{O}_{2}$ group cells were treated with $\mathrm{H}_{2} \mathrm{O}_{2}(20,30,40,50$, $60 \mu \mathrm{mol} \mathrm{L}^{-1}$ ), the ZHP and DHP group cells were treated $K$. coccinea epicarp extracts at the concentration of 25,50, 100, 200 and $300 \mu \mathrm{g} / \mathrm{mL}$, Control group cells were cultured with complete $100 \%$ medium. After incubation for $24 \mathrm{~h}, 10 \mu \mathrm{L}$ of [3-(4,5-dimethylthiazol-2-yl)5-(3-carboxymethoxyphenyl)-2- (4-sulfophenyl)-2H-tetrazolium (MTS) were added and continued to be cultured for $2 \mathrm{~h}$. The absorption values of each well were measured using an automated microplate reader (SpectraMax i3X, Molecular Devices, Silicon Valley, CA, USA) at $490 \mathrm{~nm}$. The data were calculated according to the following formula: percentage of cell viability $=\left(\mathrm{OD}\right.$ of $\mathrm{H}_{2} \mathrm{O}_{2}, \mathrm{ZHP}, \mathrm{DHP}$ group $/ \mathrm{OD}$ of control group $) \times 100$.

\subsection{Determination of Protective Effect on HUVEC Injuried by $\mathrm{H}_{2} \mathrm{O}_{2}$}

HUVEC cells in logarithmic growth phase were adjusted to $4 \times 10^{3}$ cells $/ \mathrm{mL}$ and inoculated into 96-well plates. After $4 \mathrm{~h}$ incubation for the cells to grow to confluence, the different concentrations of $K$. coccinea extracts $(50,100$ and $200 \mathrm{mg} / \mathrm{mL}$ ) were added to the cells followed by another $10 \mathrm{~h}$ incubation. Then the cells were treated with $\mathrm{H}_{2} \mathrm{O}_{2}$ for $24 \mathrm{~h}$ after the original medium was removed. After that, the cell viability was measured by MTS assay.

\subsection{Determination of ROS, MDA, SOD and GR}

HUVEC cells in logarithmic growth phase were incubated in 6-well plates at a density of $1 \times 10^{5}$ cells $/ \mathrm{mL}$. After $24 \mathrm{~h}$ of incubation, the cells were grouped as described in Section 2.6 and pretreatment $K$. coccinea extracts $(50,100$ and $200 \mu \mathrm{g} / \mathrm{mL})$ was performed for $24 \mathrm{~h}$, followed by $\mathrm{H}_{2} \mathrm{O}_{2}$-induced injury for $24 \mathrm{~h}$. Then, the level of ROS, MDA, SOD and GR in the cells was tested by commercially available kits according to the manufacturer's instructions (Beyotime Biotechnology Co., Ltd., Shanghai, China). The results of SOD activity were expressed as a percentage (\%) in the blank control group.

\subsection{Statistical Analysis}

Statistical analysis was analyzed through the software SPSS (version 20 Chicago, IL, USA). One-way analysis of variance (ANOVA) was performed and the significant differences on the results were determined by Tukey's test at $5 \%$ significance level.

\section{Results}

\subsection{The TPC, TFC, TAC and Antioxidant Capacity of K. coccinea Extracts}

The results of TPC, TFC and TAC of two kinds of $K$. coccinea are shown in Table 1 , the TPC in ZHP (2.56 $\pm 0.33 \mathrm{mg} \mathrm{GAE} / \mathrm{g})$ was lower than that of DHP $(3.51 \pm 0.14 \mathrm{mg}$ GAE/g). However, the TFC and TAC in ZHP were significantly higher than that of DHP with the value of $5.94 \pm 0.30 \mathrm{mg} \mathrm{CE} / \mathrm{g}$ and $0.71 \pm 0.02 \mathrm{mg}$ Gy-3-G/g, respectively, especially for total anthocyanins in ZHP almost 3 times greater than DHP. The results of their chemical antioxidant activity also showed that there were significantly differences between the two kinds of $K$. coccinea extracts, except the DPPH radical scavenging activities of DHP exhibited higher activity than ZHP with the value of $111.57 \pm 3.10 \mu \mathrm{mol} \mathrm{TE} / \mathrm{g}$, the ABTS and FRAP value all showed significantly lower levels than that of ZHP. The relative higher level of these three bioactive compounds in ZHP may be due to its dark black epicarp. As some previous reports indicated, the dark black color peel or epicarp usually exhibit abundant anthocyanins, especially the dark varieties, being responsible for the red, or violet to black colors $[17,18]$. 
Table 1. TPC, TFC, TAC and antioxidant activity of ZHP and DHP.

\begin{tabular}{ccccccc}
\hline Sample & $\begin{array}{c}\text { TPC } \\
(\mathbf{m g ~ G A E} / \mathbf{g})\end{array}$ & $\begin{array}{c}\text { TFC } \\
(\mathbf{m g ~ C E} / \mathbf{g})\end{array}$ & $\begin{array}{c}\text { TAC } \\
(\mathbf{m g ~ G y}-3-G / g)\end{array}$ & $\begin{array}{c}\text { DPPH } \\
(\boldsymbol{\mu m o l ~ T E} / \mathbf{g})\end{array}$ & $\begin{array}{c}\text { ABTS } \\
(\boldsymbol{\mu m o l ~ T E} / \mathbf{g})\end{array}$ & $\begin{array}{c}\text { FRAP } \\
(\boldsymbol{\mu m o l ~ T E} / \mathbf{g})\end{array}$ \\
\hline ZHP & $2.56 \pm 0.33^{\mathrm{b}}$ & $5.94 \pm 0.30^{\mathrm{a}}$ & $0.71 \pm 0.03^{\mathrm{a}}$ & $100.53 \pm 2.93^{\mathrm{a}}$ & $68.70^{\mathrm{a}} \pm 1.24^{\mathrm{a}}$ & $115.23 \pm 3.48^{\mathrm{a}}$ \\
DHP & $3.51 \pm 0.14^{\mathrm{a}}$ & $4.33 \pm 0.45^{\mathrm{b}}$ & $0.20 \pm 0.02^{\mathrm{b}}$ & $111.57 \pm 3.10^{\mathrm{a}}$ & $54.96^{\mathrm{a}} \pm 1.12^{\mathrm{b}}$ & $100.04 \pm 2.75^{\mathrm{b}}$ \\
\hline
\end{tabular}

Results are expressed as the mean $\pm \mathrm{SD}(n=3)$, (a), (b) Means with different letter within the same column indicate statistical differences $(p<0.05)$.

\subsection{The Effective Concentration of $\mathrm{H}_{2} \mathrm{O}_{2}$ and $\mathrm{K}$. coccinea Extracts on HUVEC}

Figure 2a shows the effective concentration of $\mathrm{H}_{2} \mathrm{O}_{2}$ and polyphenolics on HUVEC. The survival rate of HUVEC cells gradually decreased with the increase of $\mathrm{H}_{2} \mathrm{O}_{2}$ concentration $(20-60 \mu \mathrm{mol} / \mathrm{L})$, and decreased by $53.86 \%$ when exposed to $40 \mu \mathrm{mol} \mathrm{L}{ }^{-1}$ of $\mathrm{H}_{2} \mathrm{O}_{2}$, when the $\mathrm{H}_{2} \mathrm{O}_{2}$ continued to increase to 50 and $60 \mu \mathrm{mol} \mathrm{L}{ }^{-1}$, the cell survival rate decreased by $39.74 \%$ and $31.80 \%$, respectively. In order to achieve the best conditions for the establishment of the cell oxidative damage model, the $54 \%$ was considered an appropriate survival rate for the continued test of the degree of cell damage, as the oxidative injury was recoverable under the impact of $40 \mu \mathrm{mol} / \mathrm{L} \mathrm{H}_{2} \mathrm{O}_{2}$ solutions. Thus, concentration of $40 \mu \mathrm{mol} \mathrm{L}{ }^{-1}$ of $\mathrm{H}_{2} \mathrm{O}_{2}$ was selected for the subsequent experiments. The non-toxic concentrations of $K$. coccinea extracts on cell viability were also determined using MTS and the results are shown in Figure 2b,c. At the treatment of 300 and $400 \mu \mathrm{g} / \mathrm{mL}$ of ZHP, the cell viability was decreased by $55.86 \%$ and $20.36 \%$, respectively, but non-toxic effect was observed in DHP. Therefore, considering the cell death caused by the toxicity of the sample itself during the experiment, three concentrations of low $(50 \mu \mathrm{g} / \mathrm{mL})$, medium $(100 \mu \mathrm{g} / \mathrm{mL})$ and high $(200 \mu \mathrm{g} / \mathrm{mL})$ were selected for subsequent experiments.
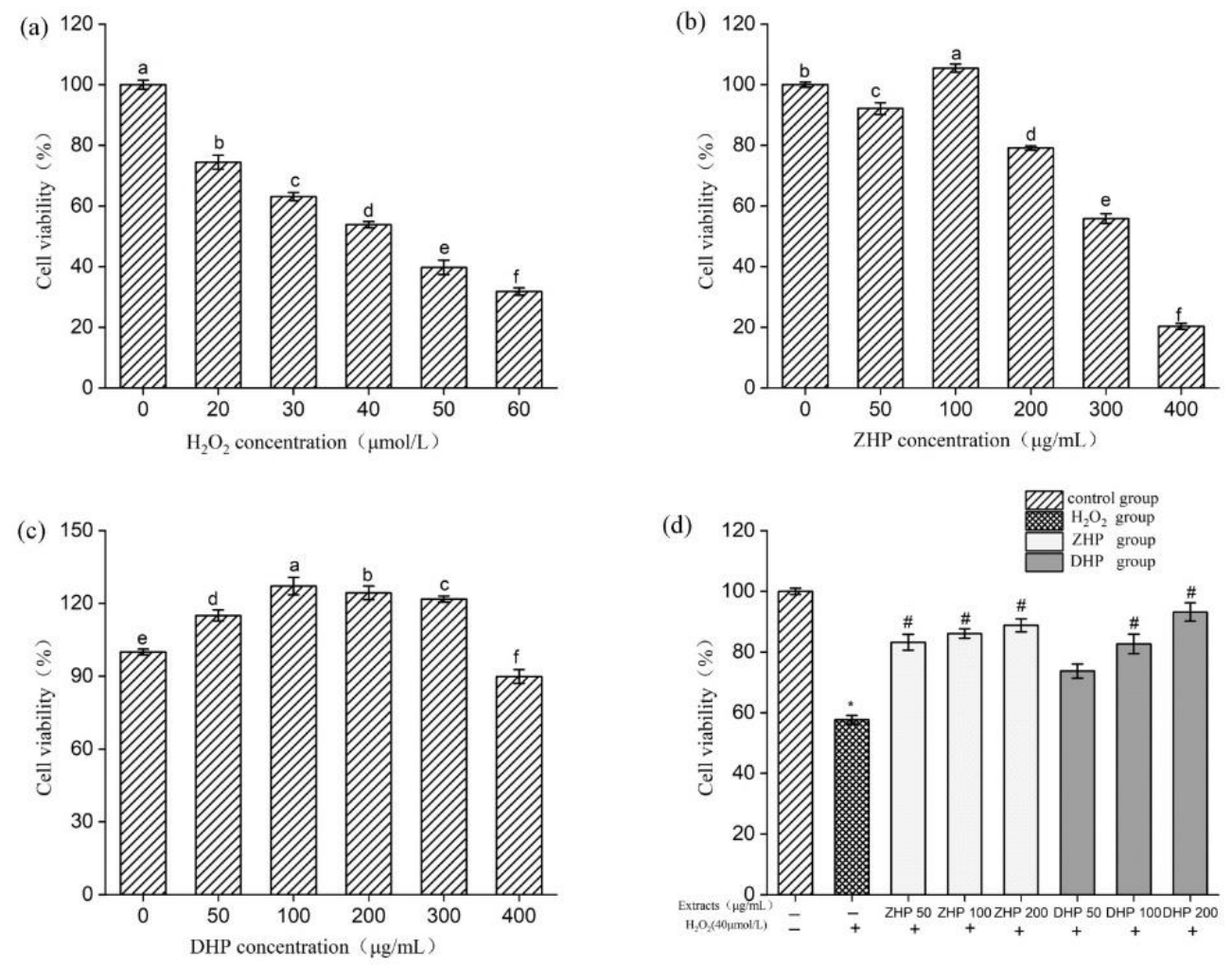

Figure 2. Effects of $\mathrm{H}_{2} \mathrm{O}_{2}(\mathbf{a})$; $\mathrm{ZHP} \mathrm{(b);} \mathrm{and} \mathrm{DHP} \mathrm{(c)} \mathrm{on} \mathrm{cell} \mathrm{viability} \mathrm{of} \mathrm{HUVEC.} \mathrm{The} \mathrm{protective} \mathrm{effects}$ of DHP and ZHP on cell viability after $\mathrm{H}_{2} \mathrm{O}_{2}$ injury (d). Values are presented as means $\pm \mathrm{SD}(n \geq 6)$; $p<0.05 ;{ }^{*} p<0.05$ vs. Control group. \# $p<0.05$ vs. $\mathrm{H}_{2} \mathrm{O}_{2}$ group. 


\subsection{Effect of K. coccinea Extracts on Survival Rate of HUVEC after $\mathrm{H}_{2} \mathrm{O}_{2}$-Induced Injury}

The protective effect of DHP and ZHP on cell viability of injured HUVEC is shown in Figure $2 \mathrm{~d}$. Under the treatment of $100 \mu \mathrm{mol} / \mathrm{mL} \mathrm{H}_{2} \mathrm{O}_{2}$ without $\mathrm{K}$. coccinea extracts, the cell survival decreased to $57.68 \%$. On the contrary, after pretreatment with the $\mathrm{K}$. coccinea extracts, the viability rate of HUVEC was markedly increased with a dose-dependent relationship. The viability rate of HUVEC cells increased by $35.50 \%$ and $31.13 \%$, respectively, compared to the injured group when pretreatment with $200 \mu \mathrm{g} / \mathrm{mL}$ of ZHP and DHP, indicating that the extracts had a positive protective effect on HUVEC cells injured by $\mathrm{H}_{2} \mathrm{O}_{2}$ cytotoxicity.

\subsection{Effect of K. coccinea Extracts on ROS of HUVEC after $\mathrm{H}_{2} \mathrm{O}_{2}$-Induced Injury}

The effect of $\mathrm{K}$. coccinea extracts on ROS content in $\mathrm{H}_{2} \mathrm{O}_{2}$-injuried HUVEC cells is shown in Figure $3 b$, cells that were exposed to $\mathrm{H}_{2} \mathrm{O}_{2}$ stress had a significant increase in intracellular ROS (nearly 3-fold vs. the control group). However, stronger inhibitory activity for the ROS overproduction was observed, and the ROS content wase markedly decreased when the cells were pretreated with 50,100 and $200 \mu \mathrm{g} / \mathrm{mL}$ of K. coccinea extracts compared to the $\mathrm{H}_{2} \mathrm{O}_{2}$ group, and the ROS content decreased as the concentration of K. coccinea extracts increased. The ROS content of the HUVEC decreased by $61.53 \%$ and $51.92 \%$, respectively, when the pretreatment concentration of ZHP and DHP were set at $200 \mu \mathrm{g} / \mathrm{mL}$, significantly lower than that in the injured group. Thus, it can be seen that the $K$. coccinea extracts can eliminate or inhibit $\mathrm{H}_{2} \mathrm{O}_{2}$-induced ROS production in cells and protect damaged HUVEC cells.
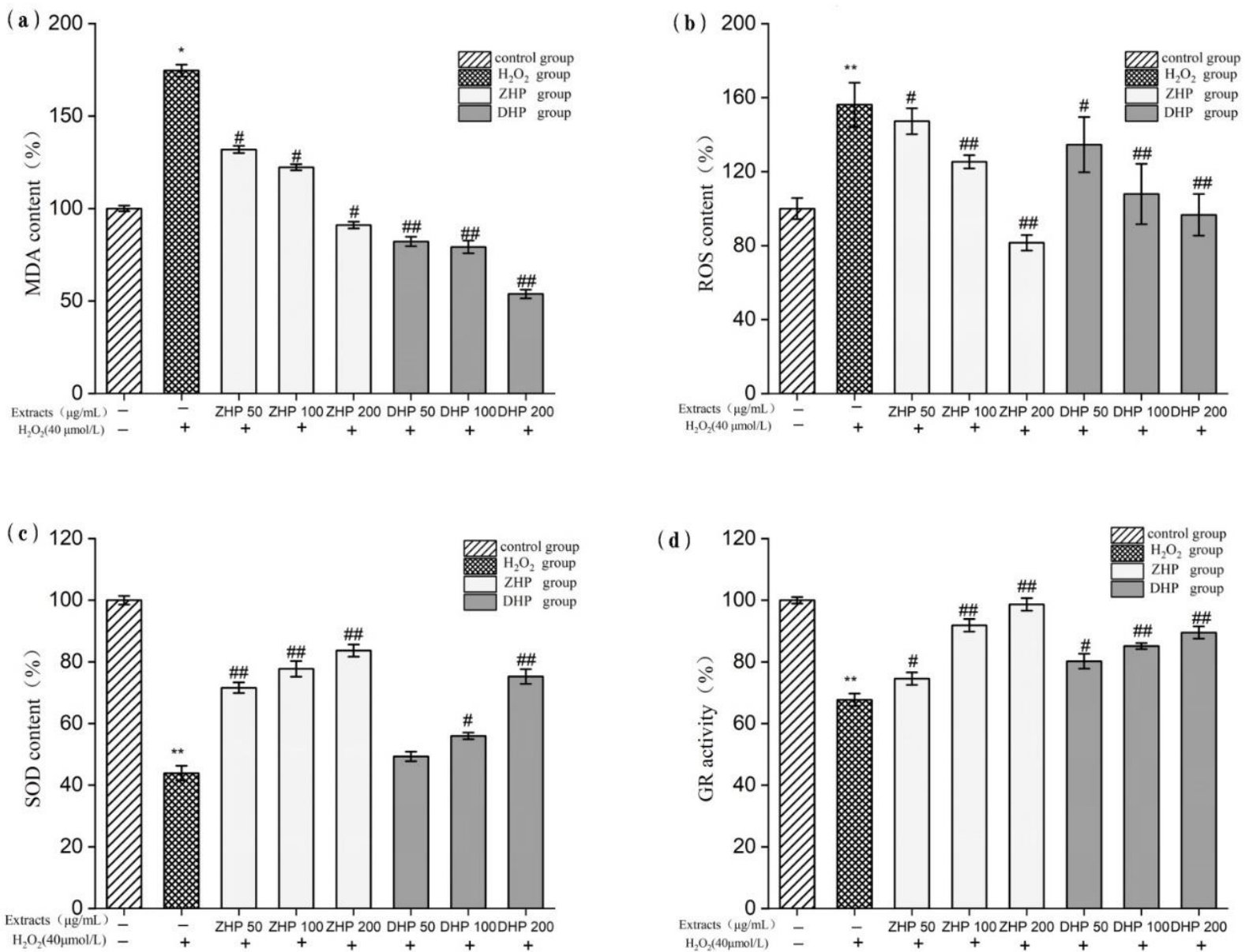

Figure 3. Effect of the DHP and ZHP on ROS content (a); MDA content (b); SOD activity (c); and GR activity (d) in HUVEC. Values are presented as means $\pm \operatorname{SD}(n \geq 6) ;{ }^{*} p<0.05 ;{ }^{* *} p<0.01 \mathrm{vs}$. Control group. \# $p<0.05 ; \#$; $<0.01$ vs. $\mathrm{H}_{2} \mathrm{O}_{2}$ group. 


\subsection{Effect of K. coccinea Extracts on MDA of HUVEC after $\mathrm{H}_{2} \mathrm{O}_{2}$-Induced Injury}

In the process of degradation of the lipid peroxides, the content of MDA is related to the level of oxidative stress, and excessive free radicals will increase the content of MDA, subsequently leading to the destruction of the structure and function of cell membrane and accelerating the aging of cell membrane. As can be seen from Figure 3a, cells that were exposed to $\mathrm{H}_{2} \mathrm{O}_{2}$ stress had a significant increase in intracellular MDA (nearly 1.74-fold vs. the control group). On the contrary, the overproduction of MDA was significantly inhibited when the cells were pretreated with different sample concentrations, particularly at $200 \mu \mathrm{g} / \mathrm{mL}$, the MDA content in the DHP and ZHP groups decreased by 91.04 and $53.80 \%$, respectively, which was much lower than that in the $\mathrm{H}_{2} \mathrm{O}_{2}$ group. This was probably due to the flavonoids that have lipophilic properties, so they can remove the lipid peroxides in the phospholipid bilayer of cell membranes. Thus, $K$. coccinea phenolics can play a protective role on the cell membrane to effectively inhibit the generation of MDA and reduce the degree of oxidative damage of HUVEC cells.

\subsection{Effect of $\mathrm{K}$. coccinea Extracts on SOD of HUVEC after $\mathrm{H}_{2} \mathrm{O}_{2}$-Induced Injury}

As the key antioxidant enzyme in the body, SOD is the enzyme that reacts to oxygen free radicals and has the strongest reaction to oxidative stress. As shown in Figure 3c, when the HUVEC was treated with $40 \mu \mathrm{mol} / \mathrm{mL}$ of $\mathrm{H}_{2} \mathrm{O}_{2}$, the SOD activity had approximately $57 \%$ of reduction, which was notable lower than that in the control group, suggesting that the HUVEC cells had been significantly injured by oxidation. However, when pretreated with polyphenolics extracts at 50 200 $\mu \mathrm{g} / \mathrm{mL}$, the SOD activity was significantly increased with an obvious dose-dependent relationship. In particular, after $200 \mu \mathrm{g} / \mathrm{mL}$ of epicarp extracts were pretreated, the SOD activity in ZHP and DHP groups was 1.9 and 1.7 times that of the $\mathrm{H}_{2} \mathrm{O}_{2}$ group, respectively, or 70 90\% of the control group. These results indicate that $K$. coccinea phenolics extracts have obvious protective effects on cells against $\mathrm{H}_{2} \mathrm{O}_{2}$ induced oxidative stress.

\subsection{Effect of Extracts on GR of HUVEC after $\mathrm{H}_{2} \mathrm{O}_{2}$-Induced Injury}

GR is a widely available oxidoreductase, which can catalyze NADPH to reduce GSSG to GSH, and plays a key role in the removal of reactive oxygen species in the oxidative stress reaction. Compared with the control group, the GR activity was dramatically decreased to $67.75 \%$ under the treatment of $40 \mu \mathrm{mol} / \mathrm{mL}$ of $\mathrm{H}_{2} \mathrm{O}_{2}$ (Figure 3d). Whereas, after pretreatment with ZHP and DHP, the GR activity sharply increased with a dose-dependent matter. Especially at the concentration of $200 \mu \mathrm{g} / \mathrm{mL}$, the GR activity reached $98.68 \%$ and $89.53 \%$, which was 1.5 and 1.3 times that of the $\mathrm{H}_{2} \mathrm{O}_{2}$ group, respectively. These results also indicate that the preventive model is sufficiently effective to relieve oxidative stress, even at lower concentrations and shorter pre-exposure to these compounds. The results also suggest that, even at lower concentrations and shorter pre-pretreatment, K. coccinea phenolics extracts can effectively reduce the HUVEC damage caused by oxidative stress.

\subsection{Phenolics Composition of K. coccinea}

The phenolic profiles of the two kinds of K. coccinea were performed based on optimized UPLC-QTOP-MS/MS methods. The individual phenolics compounds were identified by comparing the retention times and fragment ions with those of the respective standards (Table 2). Samples were tested in both positive and negative modes, but results were better in the negative mode. Thirteen phenolic compounds were identified in $K$. Coccinea (Figure 4). Among them, seven compounds belong to flavonoids (delphinidin-3xylosylrutinoside, cyanidin-3-glucosylrutinoside, cyanidin-3-xylosylrutinoside, cyanidin-3rutinoside, rutin, vitexin, hyperoside), and six compounds ( $p$-coumaric acid, ferulic acid, vanillic acid, hydroxybenzoic acid, protocatechuic acid, syringic acid) belong to phenolic acids. 
Table 2. Compositions and content of phenolic compounds from Kadsura coccinea epicarp tested by UPLC-QTOF-MS/MS.

\begin{tabular}{|c|c|c|c|c|c|c|c|}
\hline \multirow{2}{*}{\multicolumn{2}{|c|}{$\begin{array}{l}\text { Rention Time } \\
\text { (min) }\end{array}$}} & \multirow{3}{*}{$\begin{array}{c}\begin{array}{c}\text { Molecular Weight } \\
\text { (M.W) }\end{array} \\
742\end{array}$} & \multirow{3}{*}{$\begin{array}{c}\begin{array}{c}{[\mathbf{M}-\mathrm{H}]^{-} /[\mathbf{M}-\mathrm{H}]^{+}} \\
(\mathrm{m} / \mathrm{z})\end{array} \\
743^{*}\end{array}$} & \multirow{3}{*}{$\begin{array}{c}\text { Characteristic Ion }(\mathrm{m} / \mathrm{z}) \\
303.05\end{array}$} & \multirow{3}{*}{$\begin{array}{c}\text { Identified Compounds } \\
\text { delphinin-3-xylosylrutinoside }\end{array}$} & \multicolumn{2}{|c|}{ Compounds Content (mg/100 g) } \\
\hline & & & & & & \multirow{2}{*}{$\begin{array}{c}\text { ZHP } \\
98.09 \pm 0.67\end{array}$} & \multirow{2}{*}{$\begin{array}{c}\text { DHP } \\
15.90 \pm 0.49\end{array}$} \\
\hline 1 & 4.372 & & & & & & \\
\hline 2 & 4.387 & 154 & 153 & $109.02,108.02,91.01$ & protocatechuic acid & $350.74 \pm 2.58$ & $369.71 \pm 2.70$ \\
\hline 3 & 4.444 & 756 & $757 *$ & 287.05 & cyanidin-3-glucosylrutinoside & $117.85 \pm 2.99$ & $94.31 \pm 1.42$ \\
\hline 4 & 4.535 & 726 & $727 *$ & 287.05 & cyanidin-3-xylosylrutinoside & $1423.38 \pm 29.68$ & $148.37 \pm 1.39$ \\
\hline 5 & 4.601 & 594 & $595 *$ & 287.05 & cyanidin-3-rutinoside & $264.59 \pm 1.80$ & $221.76 \pm 6.83$ \\
\hline 6 & 4.896 & 138 & 137 & $93.03,65.03$ & $p$-hydroxybenzoic acid & $42.00 \pm 4.83$ & $72.09 \pm 1.70$ \\
\hline 7 & 5.286 & 168 & 167 & $152.01,108.02,91.01$ & vanillic acid & $49.44 \pm 3.72$ & $51.31 \pm 2.82$ \\
\hline 8 & 5.450 & 198 & 197 & $182.02,123$ & syringic acid & $11.15 \pm 0.98$ & $12.85 \pm 1.37$ \\
\hline 9 & 5.601 & 610 & 609 & $301,300,271$ & rutin & $795.44 \pm 15.26$ & $7.27 \pm 0.49$ \\
\hline 10 & 5.952 & 432 & 431 & $341.06,311.05,283.06$ & vitexin & $1.75 \pm 0.11$ & $1.81 \pm 0.50$ \\
\hline 11 & 6.027 & 464 & 463 & $301.03,300.02$ & hyperoside & $8.36 \pm 0.56$ & $1.61 \pm 0.24$ \\
\hline 12 & 6.095 & 164 & 163 & $119.05,93.03,65.03$ & $p$-coumaric acid & $19.15 \pm 1.97$ & $23.64 \pm 2.23$ \\
\hline 13 & 6.667 & 194 & 193 & $178.02,134.05,133.02$ & ferulic acid & $6.14 \pm 0.95$ & $8.21 \pm 0.13$ \\
\hline
\end{tabular}

Results are expressed as the mean $\pm \mathrm{SD}(n=3)$. The band * indicates detection in positive ion mode. 


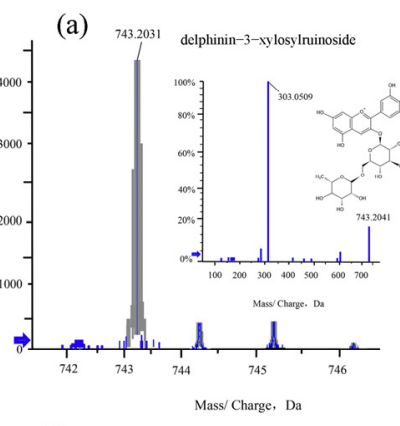

(d)
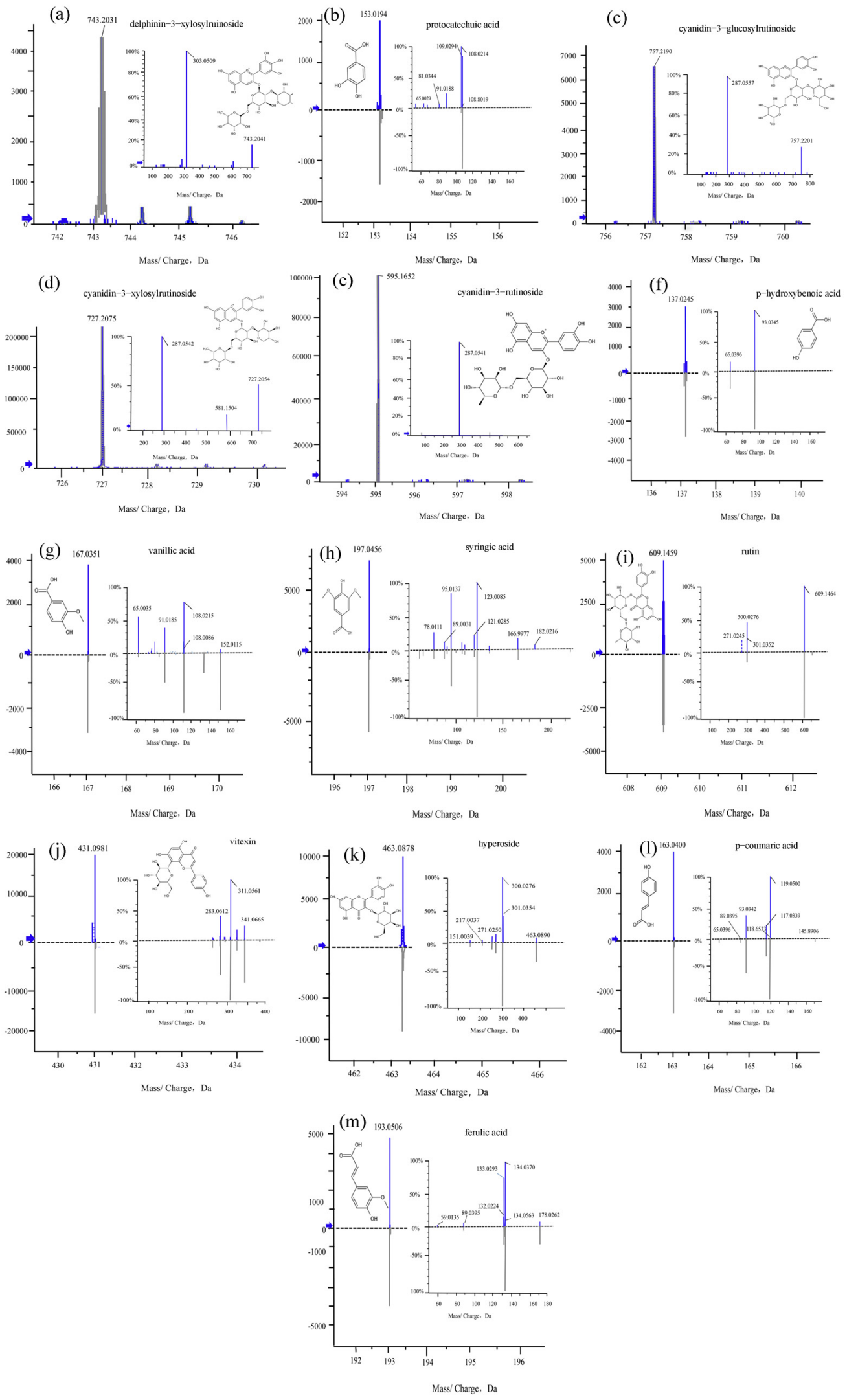

Figure 4. QTOF-MS/MS mass spectra of fragment ion and chemical structures of delphinin3-xylosylrutinoside (a); protocatechuic acid (b); cyanidin-3-glucosylrutinoside (c); cyanidin-3xylosylrutinoside (d); cyanidin-3-rutinoside (e); p-hydroxybenzoic acid (f); vanillic acid (g); syringic acid (h); rutin (i); vitexin (j); hyperoside (k); p-coumaric acid (1); ferulic acid (m). 
Compound 1 displayed molecular ion $m / z 743.20[\mathrm{M}+\mathrm{H}]^{+}$and fragment ion at $m / z$ 303.05. The $303.05[\mathrm{M}+\mathrm{H}]^{+}$was generated after the loss of glucose moiety $(162 \mathrm{Da})$, xylose glycosyl (132 Da) and rhamnose moiety (146 Da) from the $743.20[\mathrm{M}+\mathrm{H}]^{+}$, according to the fragment ion peak characteristics and the results reported by Toki [19] and Hao et al. [20]. Compound 1 was tentatively identified as delphinidin-3-xylosylrutinoside. Compound 2 exhibited $[\mathrm{M}-\mathrm{H}]^{-}$ion at $m / z$ 153.01. Sequential fragmentation gave origin to product ions at $m / z$ 109.02,108.02 and 91.01. The fragment at $m / z 109.02$ [M-H-44] ${ }^{-}$corresponded with the loss of one molecule of $\mathrm{CO}_{2}$ from $\mathrm{m} / \mathrm{z}$ 153.01, while $\mathrm{m} / \mathrm{z}$ 91.01 [M-H-44-18] ${ }^{-}$ was generated by losing one molecule of $\mathrm{H}_{2} \mathrm{O}$ from $m / z$ 109.02. When compared to the standard information and literature [21], compound 2 was identified as protocatechuic acid.

Compound 3 displayed a molecular ion $m / z 757.22[\mathrm{M}+\mathrm{H}]^{+}$and a fragment ion at $m / z 287.05$ which corresponded to the cyanidin aglycone. The $287.05[\mathrm{M}+\mathrm{H}]^{+}$was generated after the loss of two glucose moiety (162 Da) and rhamnose moiety (146 Da) from the $m / z 757.22[\mathrm{M}+\mathrm{H}]^{+}$, which suggested that the compound was one of the anthocyanins in centaurea cyanus. These results were consistent with the characteristic ion of sour cherry [22] and mulberry [23]. Therefore, compound 3 was identified as cyanidin-3-glucosylrutinoside.

Compound 4 displayed a molecular ion $m / z 727.21[\mathrm{M}+\mathrm{H}]^{+}$and a fragment ion at $m / z 287.05$, which was generated after the loss of glucose moiety (162 Da), xylose moiety (132 Da) and rhamnose moiety (146 Da) from the $m / z 727.21[\mathrm{M}+\mathrm{H}]^{+}$, suggested that the compound was one of anthocyanins in centaurea cyanus. This fragmentation pattern coincides with black raspberry [24] and omija (Schizandra chinensis) fruit [25]. Therefore, compound 4 was identified as cyanidin-3-xylosylrutinoside.

Compound 5 displayed a molecular ion $m / z 595.17[\mathrm{M}+\mathrm{H}]^{+}$and a fragment ion at $m / z 287.05$. This fragment was assumed to be the result of the loss of glucose moiety (162 Da) and rhamnose moiety (146 Da) from the $m / z 595.17[\mathrm{M}+\mathrm{H}]^{+}$, suggesting that the compound was one of the anthocyanins in centaurea cyanus, and when compared with the mass spectrum characteristic found in sour cherry [22] and cranberry [26]. Thus, compound 5 was identified as cyanidin-3-rutinoside.

Compound 6 displayed [M-H] $]^{-}$ion at $m / z 137.02$ and two fragment ions at $m / z 93.03$ and 65.03. The fragment ion at $m / z 93.03$ [M-H-44] $]^{-}$was generated by losing one molecule of $\mathrm{CO}_{2}$ from $m / z$ 137.02. Further $\mathrm{MS}^{n}$ fragmentation gave origin to product ion at $m / z$ 65.03 [M-H-44-28] $]^{-}$by the loss of one molecule of $\mathrm{CO}$. When compared with the standard information and literature [27], compound 6 was identified as p-hydroxybenzoic acid.

Compound 7 exhibited molecular ion at $m / z 167.03[\mathrm{M}-\mathrm{H}]^{-}$with three fragment ions at $m / z$ 152.01, 108.02 and 91.01. The molecular ion $m / z 167.03$ loss of one molecule of $\mathrm{CH}_{3}$ generated $m / z$ 152. 01 [M-H-15] $]^{-}$, which further lost one molecule of $\mathrm{CO}_{2}$ giving $m / z$ 108.02 [M-H-15-44] ${ }^{-}$, and then further lost one molecule of $\mathrm{C}_{2} \mathrm{H}_{3}$ giving $m / z 91.01$ [M-H$15-44-27]^{-}$. When compared with the standard information and literature [27], compound 7 was identified as vanillic acid.

Compound 8 generated a molecular ion at $m / z 197.04[\mathrm{M}-\mathrm{H}]^{-}$and two fragments, one at $m / z 182.02$ and the other at $m / z 123$. The first fragment was generated as $m / z 197.04$, lost one molecule of $\mathrm{CH}_{3}$ and formed fragment ion $m / z 182.02$ [M-H-15] ${ }^{-}$. The $m / z 123$ resulting from the $m / z 182.02$ loss of one molecule of $\mathrm{CH}_{3}$ and $\mathrm{CO}_{2}$. When compared with the standard information and literature [27], compound 8 was identified as syringic acid.

Compound 9 exhibited molecular ion of $m / z 609.15[\mathrm{M}-\mathrm{H}]^{-}$with three fragment ions at $m / z 301.03,300.02$ and 271.02. Among these fragments, the $m / z 301.03$ was generated as aglycone Sour $\left.\mathrm{hY}_{0}\right]^{-}$resulting from parent ion $m / z 609.15$ then lost the rutinose moiety, which further lost one molecule of $\mathrm{H}_{2} \mathrm{CO}$ to yield $\mathrm{m} / z$ 271.02. Compound 9 was identified as rutin, based on the standard information and literature [28].

Compound 10 showed a parent ion $m / z 431.1$ and two fragment ions at $m / z 341.06$ and 311.05. The fragment ion at $m / z 341.06$ [M-H-90] and $m / z 311.05$ [M-H-120] were produced by the loss of $\mathrm{C}_{3} \mathrm{H}_{6} \mathrm{O}_{3}$ and $\mathrm{C}_{4} \mathrm{H}_{8} \mathrm{O}_{4}$ which resulted from the cleavage of sugar chains, respectively. Fragment ions $m / z 283$ were generated as $m / z$ 341continued to 
lose one molecule of $\mathrm{H}_{2} \mathrm{O}$ and $\mathrm{CO}$. When compared with the standard information and literature [29], compound 10 was identified as vitexin.

Compound 11 exhibited a molecular ion at $m / z 463.09[\mathrm{M}-\mathrm{H}]^{-}$and two fragment ions at $m / z 301.03$ and 300.02. The fragment ion at $m / z 301.03$ was generated as aglycone $\left[\mathrm{Y}_{0}\right]^{-}$ resulting from the molecular ion loss at $m / z$ 162.16, which corresponded with the loss of the galactopyranose moiety. Fragment ions $m / z 300.02$ were generated as $\left[\mathrm{Y}_{0}-\mathrm{H}\right]^{-}$. When compared with the standard information and literature [30], compound 11 was identified as hyperoside.

Compound 12 showed a $[\mathrm{M}-\mathrm{H}]^{-}$at $m / z 163.04$ and gave three fragment ions at $m / z$ $119.05,93.03$ and 65.03. The fragment ion at $m / z 119.05[\mathrm{M}-\mathrm{H}-44]^{-}$was generated by the loss of one molecule of $\mathrm{CO}_{2}$ from $m / z$ 163.04. The fragment ion at $m / z 93.03$ [M-H-56-14] ${ }^{-}$ resulted from the loss of two molecules of $\mathrm{CO}$ and one molecule of $\mathrm{CH}_{2}$ from $m / z 163.04$. When compared with the standard information and literature [27], compound 12 was identified as $p$-coumaric acid.

Compound 13 generated the molecular ion $m / z[\mathrm{M}-\mathrm{H}]^{-} 193.05$ and three fragment ions at $m / z 178.02,134.05$ and 133.02. The fragment ion at $m / z 178.02$ [M-H-15] ${ }^{-}$corresponded to the loss of one molecule of $\mathrm{CH}_{3}$ from $\mathrm{m} / z$ 193.05, which further lost one molecule of $\mathrm{CO}_{2}$ giving $m / z 134.05$ [M-H-15-44] $]^{-}$. When compared with the standard information and literature [27], compound 13 was identified as ferulic acid.

\subsection{Quantitation of Phenolic Compounds Content in Polyphenol Extracts}

Concentrations of phenolics were determined from peak area measurements in comparison to a standard curve, except anthocyanin. As there was a lack of corresponding standards, these anthocyanins with complex glycosylation were quantified based on cyanidin-3-glucoside. The mass concentration of each phenolic compounds in K. coccinea are summarized in Table 2. Amongst them, anthocyanin were the predominant phenolic compounds in K. coccinea epicarp with the value of $1903.88 \mathrm{mg}$ Gy-3-G/100 g in ZHP and $480.34 \mathrm{mg}$ Gy-3-G/100 g in DHP, approximately accounting for $60 \%$ and $47 \%$ of total phenolics amount in ZHP and DHP, respectively, which was significantly higher than the proportions of hydroxybenzoic acids (14 49\%), hydroxycinnamic acids $(1 \sim 3 \%)$ and nonanthocyanins flavonoids (1 25\%). Amongst anthocyanins, cyanidin-3-xylosylrutinoside and cyanidin-3-rutinoside have been indicated as the dominant components present in $K$. coccinea, in particular cyanidin-3-xylosylrutinoside was the most abundant anthocyanin. These results are consistent with data obtained by Hao et al. [20]. In this paper, there was $1423.38 \pm 29.68 \mathrm{mg}$ Gy-3-G/100 g and $148.37 \pm 1.39 \mathrm{mg} \mathrm{Gy-3-G/100} \mathrm{g} \mathrm{in} \mathrm{ZHP} \mathrm{and}$ DHP, accounting for $74.76 \%$ and $30.89 \%$ of the total amount of anthocyanins, respectively. The present results were also significantly higher than that of the Chinese dwarf cherry $(0.42 \pm 0.11 \mathrm{mg}$ Gy-3-G/kg) [31] and $11.22 \mathrm{mg} / 100 \mathrm{~g}$ in redcurrant [32]. Cyanidin-3rutinoside might be the secondly highest anthocyanin in $\mathrm{K}$. coccinea extracts with the value of $264.59 \pm 1.80$ and $221.76 \pm 6.83 \mathrm{~Gy}-3-\mathrm{G} / 100 \mathrm{~g}$ in ZHP and DHP, respectively, significantly higher than that that of the Rubus coreanus with 3.5 78 mg Gy-3-G/100 g [33], also higher than that of Ribes, Aronia, and Sambucus with the value of $5.83 \mathrm{mg} / 100 \mathrm{~g}$ and cloudberry (wild) with the value of $1.86 \mathrm{mg}$ Gy-3-G/100 g [34]. The cyanidin-3-glucosylrutinoside content in K. coccinea extracts was $117.85 \pm 2.99 \mathrm{mg}$ Gy-3-G 100/g in ZHP and $94.31 \pm 1.42 \mathrm{mg}$ Gy-3-G/100g in DHP, which was higher than that of in Raspberry-Rubus idaeus L with $27.95 \mathrm{mg}$ Gy-3-G 100/g [34], and comparable to those in redcurrant reported by the authors in [35] and in sour cherry reported by the authors in [36] (7.64 mg Gy-3-G/100 g and $109.70 \mathrm{mg}$ Gy-3-G/100 g, respectively). Another minor amount of anthocyanin was delphinidin 3-xylosylrutinoside with the value of $98.09 \pm 0.67 \mathrm{mg}$ Gy-3-G/100 $\mathrm{g}$ in ZHP and $15.9 \pm 0.49 \mathrm{mg}$ Gy-3-G/100g in DHP. It was rarely reported in fruits and only found in the petals of linum grandiflorum [19].

The total amount of non-anthocyanin flavonoids include two flavonols (rutin, hyperoside) and one flavone (vitexin)in K. coccinea was up to $805.55 \mathrm{mg} / 100 \mathrm{~g}$. Among them, rutin accounted for $98.70 \%$ of the total amount of total flavonoids. To the best of our 
knowledge, these flavonoids have not been reported so far, in $K$. coccinea. The highest level of phenolic acid observed in $K$. coccinea was protocatechuic acid with the value of $369.71 \pm 2.70 \mathrm{mg} / 100 \mathrm{~g}$ in DHP, which represented $35.93 \%$ of the total of phenolic compounds, and slightly higher than that of ZHP with the value of $350.74 \pm 2.58 \mathrm{mg} / 100 \mathrm{~g}$. Hydroxybenzoic acid and vanillic acid were present at comparable levels (42 72 mg/100 g) in DHP and ZHP. Traces of $p$-coumaric acid, ferulic acid and syringic acid were all detected in these two kinds of $K$. coccinea.

Interestingly, the content of individual phenolic acids in ZHP were all lower than that of DHP, whereas the content of all anthocyanins, rutin and heperoside in ZHP exhibited higher levels than that of DHP. These concentration differences were supposed to be related to the visual color, as the darker the color, the higher were the levels of anthocyanins. The present difference in phenolics' quantitation results, combined with those of radical scavenging activities, indicate that these biological activities are most likely ascribed to the dominant phenolic compounds such as cyanidin-3-xylosylrutinoside, cyanidin-3-rutinoside, rutin, protocatechuic acid and hyperoside in K. coccinea extracts, especially for cyanidin-3-xylosyl-rutinoside, which was nearly ten times higher than DHP extract. Kim et al. [25] reported that the cyanidin-3-xylosylrutinoside from Omija pigment mostly explained 86\% (DPPH) and 98\% (ABTS) of total antioxidant activity. Im et al. in [37] reported that cyanidin-3-xylosylrutinoside, yanidin-3-rutinoside, cyanidin-3-sambubioside and cyanidin-3-glucoside were dominant components and contributors to the antioxidant capacity of ripe $R$. coreanus Miquel fruits for the protective effect on neuronal PC-12 cells induced by $\mathrm{H}_{2} \mathrm{O}_{2}$ [37]. The probable protective mechanism for cyanidin glycosides, was proved to possess the effect on oxygen species (ROS)-with the dependent activation of p38 MAPK and JNK [38]. Rutin, as a popular flavonoid, also showed a greater protective effect on the injured HUVECs caused by $\mathrm{H}_{2} \mathrm{O}_{2}$ through a decrease in the level of malondialdehyde (MDA), lactate dehydrogenase (LDH), and an increase in the level of nitrogen oxide (NOS) [39], or a reduction in the ROS, calpain and ceramide levels in mouse kidneys [40]. It was also reported that rutin could upregulate NRF2-mediated endogenous antioxidant responses by oxidizing to quinone to protect HUVECs from oxidative stress induced by $\mathrm{H}_{2} \mathrm{O}_{2}$ [41]. Protocatechuic acid as one of the primary metabolites of cyanidin3-glucoside and cyanidin-3-rutinoside, also showed protective effects on hepatotoxicity induced by cisplatin in mice, through reducing MDA and NO levels and increasing GSH and SOD levels [42], could also reduce palmitic acid-induced oxidative damage to human umbilical vein endothelial cells (HUVECs) or high-fat diet-induced aortic oxidative damage in mice $[43,44]$. Therefore, a better biological activity of ZHP might be partially attributed to these compounds.

From the discussion above, these phenolic components constitute the material basis against oxidative stress activity for K. coccinea, in spite of the detailed molecular mechanisms remaining to be clearly studied. However, the present study could be the first to demonstrate that the anthocyanin-rich phenolics of $K$. coccinea positively affect SOD and GR production as part of the cellular antioxidant mechanism. The results showed that this fruit is an excellent source of phenolic compounds with important antioxidant potential, which provides an important option for the pharmaceutical industry, or as a functional food to develop new natural plant products to combat oxidative stress.

\section{Conclusions}

In the present study, a validated UPLC-QTOF-MS/MS method was employed for the rapid simultaneous quantitative determination of phenolic compounds in K. coccinea. Thirteen phenolic compounds were successfully identified and quantified including anthocyanins, flavan-3-ols, flavonols and phenolic acids. For the first time to our knowledge, vitexin, rutin and heperoside were found for the first time in $K$. coccinea. The anthocyaninrich phenolic extracts of $K$. coccinea. not only have chemical antioxidant activity, but also can reduce the overproduction of ROS and NO and enhance the expression of antioxidant 
enzymes SOD and GR in cell bioassay. Our data provided evidence on the potential of $K$. coccinea. as a rich source of natural antioxidant molecules.

Author Contributions: Conceptualization, J.L.; Formal analysis, Y.Z.; Methodology, Z.Y., J.C. and F.L.; Resources, J.C.; Supervision, F.L.; Writing—original draft, Y.Z.; Writing—review and editing, J.L. All authors have read and agreed to the published version of the manuscript.

Funding: This work was financed by the Science and Technology Innovation Platform and Talent Project of Hunan Province (2019TP1029), the Innovation Development and Research Project for Forestry and Grassland Science and Technology of National Forestry and Grassland Administration (2020132110), the Changsha Municipal Natural Science Foundation (kq2014154).

Institutional Review Board Statement: Not applicable.

Data Availability Statement: Not applicable.

Conflicts of Interest: The authors declare no conflict of interest.

\section{References}

1. Rendra, E.; Riabov, V.; Mossel, D.M.; Sevastyanova, T.; Harmsen, M.C.; Kzhyshkowska, J. Reactive oxygen species (ROS) in macrophage activation and function in diabetes. Immunobiology 2019, 224, 242-253. [CrossRef] [PubMed]

2. Singh, U.; Jialal, I. Oxidative stress and atherosclerosis. Pathophysiology 2006, 13, 129-142. [CrossRef]

3. Pahlke, G.; Ahlberg, K.; Oertel, A.; Janson-Schaffer, T.; Grabher, S.; Mock, H.P.; Matros, A.; Marko, D. Antioxidant Effects of Elderberry Anthocyanins in Human Colon Carcinoma Cells: A Study on Structure-Activity Relationships. Mol. Nutr. Food Res. 2021, e2100229. [CrossRef] [PubMed]

4. $\mathrm{Wu}, \mathrm{Y}$;; Wang, Y.; Nabi, X. Protective effect of Ziziphora clinopodioides flavonoids against $\mathrm{H}_{2} \mathrm{O}_{2}$-induced oxidative stress in HUVEC cells. Biomed. Pharmacother. 2019, 117, 109156. [CrossRef] [PubMed]

5. Kourouma, V.; Mu, T.H.; Zhang, M.; Sun, H.N. Comparative study on chemical composition, polyphenols, flavonoids, carotenoids and antioxidant activities of various cultivars of sweet potato. Int. J. Food Sci. Technol. 2019, 55, 369-378. [CrossRef]

6. Ji, C.; Dai, S.; Liu, H.; Dong, J.; Liu, C.; Zuo, J. Polyphenols from Securidaca inappendiculata alleviated acute lung injury in rats by inhibiting oxidative stress sensitive pathways. Chin. Herb. Med. 2021, 13, 381-388. [CrossRef]

7. Rojano-Ortega, D. Regular, but not acute, green tea supplementation increases total antioxidant status and reduces exerciseinduced oxidative stress: A systematic review. Nutr. Res. 2021, 94, 34-43. [CrossRef]

8. Samtiya, M.; Aluko, R.E.; Dhewa, T.; Moreno-Rojas, J.M. Potential Health Benefits of Plant Food-Derived Bioactive Components: An Overview. Foods 2021, 10, 839. [CrossRef]

9. Liu, J.; Qi, Y.; Lai, H.; Zhang, J.; Jia, X.; Liu, H.; Zhang, B.; Xiao, P. Genus Kadsura, a good source with considerable characteristic chemical constituents and potential bioactivities. Phytomedicine 2014, 21, 1092-1097. [CrossRef]

10. Yang, Y.; Jian, Y.; Cheng, S.; Jia, Y.; Liu, Y.; Yu, H.; Cao, L.; Li, B.; Peng, C.; Iqbal Choudhary, M.; et al. Dibenzocyclooctadiene lignans from Kadsura coccinea alleviate APAP-induced hepatotoxicity via oxidative stress inhibition and activating the Nrf2 pathway in vitro. Bioorg. Chem. 2021, 115, 105277. [CrossRef]

11. Bursal, E.; Koksal, E.; Gulcin, I.; Bilsel, G.; Goren, A.C. Antioxidant activity and polyphenol content of cherry stem (Cerasus avium L.) determined by LC-MS/MS. Food Res. Int. 2013, 51, 66-74. [CrossRef]

12. Zielinski, A.A.F.; Haminiuk, C.W.I.; Alberti, A.; Nogueira, A.; Demiate, I.M.; Granato, D. A comparative study of the phenolic compounds and the in vitro antioxidant activity of different Brazilian teas using multivariate statistical techniques. Food Res. Int. 2014, 60, 246-254. [CrossRef]

13. Lee, J.; Durst, R.W.; Wrolstad, R.E. Determination of Total Monomeric Anthocyanin Pigment Content of Fruit Juices, Beverages, Natural Colorants, and Wines by the pH Differential Method: Collaborative Study. J. Aoac. Int. 2005, 88, 1269-1278. [CrossRef] [PubMed]

14. Gorjanović, S.; Komes, D.; Pastor, F.T.; Belščakcvitanović, A.; Pezo, L.; Hečimović, I.; Sužnjević, D. Antioxidant capacity of teas and herbal infusions: Polarographic assessment. J. Agric. Food. Chem. 2012, 60, 9573-9580. [CrossRef]

15. Oh, J.; Jo, H.; Cho, A.R.; Kim, S.-J.; Han, J. Antioxidant and antimicrobial activities of various leafy herbal teas. Food Control 2013, 31, 403-409. [CrossRef]

16. Lu, X.; Ross, C.F.; Powers, J.R.; Aston, D.E.; Rasco, B.A. Determination of total phenolic content and antioxidant activity of garlic (Allium sativum) and elephant garlic (Allium ampeloprasum) by attenuated total reflectance-Fourier transformed infrared spectroscopy. J. Agric. Food. Chem. 2011, 59, 5215-5221. [CrossRef]

17. Madrau, M.A.; Sanguinetti, A.M.; Caro, A.D.; Fadda, C.; Piga, A. Contribution of melanoidins to the antioxidant activity of prunes. J. Food Qual. 2010, 33 (Suppl. S1), 155-170. [CrossRef]

18. Mikulic-Petkovsek, M.; Stampar, F.; Veberic, R.; Sircelj, H. Wild Prunus Fruit Species as a Rich Source of Bioactive Compounds. J. Food Sci. 2016, 81, C1928. [CrossRef]

19. Toki, K.; Saito, N.; Harada, K.; Shigihara, A.; Honda, T. Delphinidin 3-xylosylrutinoside in petals of Linum grandiflorum. Phytochemistry 1995, 39, 243-245. [CrossRef] 
20. Hao, J.; Zhu, H.; Liu, S.; Li, H. Characterization of Anthocyanins in Fruit of Kadsura coccinea (Lem.) A.C. Smith by UPLC/Q-TOFMS Analysis and Evaluation of Stability of the Major Anthocyanins. Food Anal. Method 2013, 7, 1312-1322. [CrossRef]

21. Arivalagan, M.; Roy, T.K.; Yasmeen, A.M.; Pavithra, K.C.; Jwala, P.N.; Shivasankara, K.S.; Manikantan, M.R.; Hebbar, K.B.; Kanade, S.R. Extraction of phenolic compounds with antioxidant potential from coconut (Cocos nucifera L.) testa and identification of phenolic acids and flavonoids using UPLC coupled with TQD-MS/MS. LWT-Food Sci. Technol. 2018, 92, 116-126. [CrossRef]

22. Wojdyło, A.; Nowicka, P.; Teleszko, M. Degradation Kinetics of Anthocyanins in Sour Cherry Cloudy Juices at Different Storage Temperature. Processes 2019, 7, 367. [CrossRef]

23. Zou, T.; Wang, D.; Guo, H.; Zhu, Y.; Luo, X.; Liu, F.; Ling, W. Optimization of Microwave-Assisted Extraction of Anthocyanins from Mulberry and Identification of Anthocyanins in Extract Using HPLC-ESI-MS. J. Food Sci. 2012, 77, C46-C50. [CrossRef] [PubMed]

24. Ryu, D.; Koh, E. Stability of anthocyanins in bokbunja (Rubus occidentalis L.) under in vitro gastrointestinal digestion. Food Chem. 2018, 267, 157-162. [CrossRef]

25. Kim, S.H.; Joo, M.H.; Yoo, S.H. Structural identification and antioxidant properties of major anthocyanin extracted from Omija (Schizandra chinensis) fruit. J. Food Sci. 2009, 74, C134-C140. [CrossRef]

26. Xue, H.; Tan, J.; Zhu, X.; Li, Q.; Cai, X. Counter-current fractionation-assisted and bioassay-guided separation of active compounds from cranberry and their interaction with $\alpha$-glucosidase. LWT-Food Sci. Technol. 2021, 145, 111374. [CrossRef]

27. Zhang, L.; Li, Y.; Liang, Y.; Liang, K.; Zhang, F.; Xu, T.; Wang, M.; Song, H.; Liu, X.; Lu, B. Determination of phenolic acid profiles by HPLC-MS in vegetables commonly consumed in China. Food Chem. 2019, 276, 538-546. [CrossRef]

28. Kicel, A.; Owczarek, A.; Michel, P.; Skalicka-Woźniak, K.; Kiss, A.K.; Olszewska, M.A. Application of HPCCC, UHPLC-PDA-ESIMS 3 and HPLC-PDA methods for rapid, one-step preparative separation and quantification of rutin in Forsythia flowers. Ind. Crops Prod. 2015, 76, 86-94. [CrossRef]

29. Gai, Q.Y.; Jiao, J.; Wang, X.; Fu, Y.J.; Lu, Y.; Liu, J.; Wang, Z.Y.; Xu, X.J. Simultaneous quantification of eleven bioactive phenolic compounds in pigeon pea natural resources and in vitro cultures by ultra-high performance liquid chromatography coupled with triple quadrupole mass spectrometry (UPLC-QqQ-MS/MS). Food Chem. 2021, 335, 127602. [CrossRef]

30. Li, W.; Zhang, Y.; Shi, S.; Yang, G.; Liu, Z.; Wang, J.; Kang, W. Spectrum-effect relationship of antioxidant and tyrosinase activity with Malus pumila flowers by UPLC-MS/MS and component knock-out method. Food Chem. Toxicol. 2019, 133, 110754. [CrossRef]

31. Chen, L.; Xin, X.; Yuan, Q.; Su, D.; Liu, W. Phytochemical properties and antioxidant capacities of various colored berries. J. Sci. Food Agric. 2014, 94, 180-188. [CrossRef] [PubMed]

32. $\mathrm{Wu}, \mathrm{X}$.; Gu, L.; Prior, R.L.; McKay, S. Characterization of anthocyanins and proanthocyanidins in some cultivars of Ribes, Aronia, and Sambucus and their antioxidant capacity. J. Agric. Food Chem. 2004, 52, 7846-7856. [CrossRef] [PubMed]

33. Lee, J.; Dossett, M.; Finn, C.E. Anthocyanin fingerprinting of true bokbunja (Rubus coreanus Miq.) fruit. J. Funct. Foods 2013, 5 , 1985-1990. [CrossRef]

34. Määttä-Riihinen, K.; Kamal-Eldin, A.; Törrönen, A. Identification and quantification of phenolic compounds in berries of Fragaria and Rubus species (family Rosaceae). J. Agric. Food Chem. 2004, 52, 6178-6187. [CrossRef] [PubMed]

35. Kaisu, R.; Määttä, A.K.E.; Törrönen, A.R. High-performance liquid chromatography (HPLC) analysis of phenolic compounds in berries with diode array and electrospray ionization mass spectrometric (MS) detection: Ribes species. J. Agric. Food Chem. 2003, 51, 6736-6744.

36. Kim, D.O.; Padilla-Zakour, O.I. Jam Processing Effect on Phenolics and Antioxidant Capacity in Anthocyanin-rich Fruits: Cherry, Plum, and Raspberry. J. Food Sci. 2010, 69, S395-S400. [CrossRef]

37. Im, S.E.; Nam, T.G.; Lee, H.; Han, M.W.; Heo, H.J.; Koo, S.I.; Lee, C.Y.; Kim, D.O. Anthocyanins in the ripe fruits of Rubus coreanus Miquel and their protective effect on neuronal PC-12 cells. Food Chem. 2013, 139, 604-610. [CrossRef]

38. Feng, R.; Ni, H.M.; Wang, S.Y.; Tourkova, I.L.; Shurin, M.R.; Harada, H.; Yin, X.M. Cyanidin-3-rutinoside, a natural polyphenol antioxidant, selectively kills leukemic cells by induction of oxidative stress. J. Biol. Chem. 2007, 282, 13468-13476. [CrossRef]

39. Guo, Y.; Shen, L.; Lu, Y.; Li, H.; Min, K.; Li, L.; Yu, C.; Zheng, X. Preparation of Rutin-liposome Drug Delivery Systems and Evaluation on Their in vitro Antioxidant Activity. Chin. Herb. Med. 2016, 8, 371-375. [CrossRef]

40. Ma, J.; Liu, C.; Yang, W. Protective effect of rutin against carbon tetrachloride-induced oxidative stress, inflammation and apoptosis in mouse kidney associated with the ceramide, MAPKs, p53 and calpain activities. Chem-Biol. Interact. 2018, 286, 26-33. [CrossRef]

41. Sthijns, M.M.J.P.E.; Schiffers, P.M.; Janssen, G.M.; Lemmens, K.J.A.; Ides, B.; Vangrieken, P.; Bouwman, F.G.; Mariman, E.C.; Pader, I.; Arnér, E.S.J.; et al. Rutin protects against $\mathrm{H}_{2} \mathrm{O}_{2}$-triggered impaired relaxation of placental arterioles and induces Nrf2-mediated adaptation in Human Umbilical Vein Endothelial Cells exposed to oxidative stress. BBA-Gen. Subj. 2017, 1861, 1177-1189. [CrossRef] [PubMed]

42. Habib, S.A.; Suddek, G.M.; Abdel Rahim, M.; Abdelrahman, R.S. The protective effect of protocatechuic acid on hepatotoxicity induced by cisplatin in mice. Life Sci. 2021, 277, 119485. [CrossRef]

43. Han, L.; Yang, Q.; Li, J.; Cheng, F.; Zhang, Y.; Li, Y.; Wang, M. Protocatechuic Acid-Ameliorated Endothelial Oxidative Stress through Regulating Acetylation Level via CD36/AMPK Pathway. J. Agric. Food Chem. 2019, 67, 7060-7072. [CrossRef] [PubMed]

44. Han, L.; Yang, Q.; Ma, W.; Li, J.; Qu, L.Z.; Min, W. Protocatechuic acid ameliorated palmitic acid-induced oxidative damage in endothelial cells through activating endogenous antioxidant enzymes via an AMPK-dependent pathway. J. Agric. Food Chem. 2018, 66, 10400-10409. [CrossRef] [PubMed] 